\title{
Calcium, magnesium and phosphorus dietary intake in active and sedentary Polish students
}

\author{
Marzena Malara ${ }^{1}$, Joanna Tkaczyk ${ }^{1}$, Anna Kęska ${ }^{1}$, Grażyna Lutosławska ${ }^{1}$, Krzysztof Mazurek ${ }^{2}$ \\ ${ }^{1}$ Department of Biochemistry and Biology, Józef Piłsudski University of Physical Education, Warsaw, Poland; ${ }^{2}$ Department \\ of Physiology and Sports Medicine, Józef Piłsudski University of Physical Education, Warsaw, Poland
}

\section{Summary}

Study aim: To evaluate energy, macronutrient, calcium, magnesium, and phosphate daily intake in young healthy Polish male students.

Material and methods: Two hundred and sixteen participants were physical education students engaged in regular physical activity (about $9 \mathrm{~h} /$ week) and were recognized as physically active. One hundred and fourteen students were from other specializations participating in $1.5 \mathrm{~h} /$ week gymnastics classes and were recognized as sedentary. Body mass and height were measured using standard medical equipment. Body fat was evaluated from four skinfold measurements. In all subjects daily intake of energy, protein, fat, carbohydrates, calcium, magnesium and phosphate was briefly assessed from 24-hour food records taken over 4 days.

Results: The active students' diet was characterized by significantly higher energy, macronutrient and mineral daily intake. Moreover, calcium to phosphorus and calcium to magnesium ratios in active subjects were higher than in sedentary ones. There was no significant difference between groups in protein or magnesium intake expressed per $1000 \mathrm{kcal}$. In contrast, daily intake of fat and phosphate expressed per $1000 \mathrm{kcal}$ was significantly lower in the active students vs. sedentary ones $(\mathrm{p}<0.001$ and $\mathrm{p}<0.05$ for fat and phosphate, respectively). Active students were characterized by significantly higher carbohydrate and calcium intake per $1000 \mathrm{kcal}$ in comparison with their sedentary counterparts $(\mathrm{p}<0.001$ for both variables $)$.

Conclusions: The dietary pattern of active students was found to be slightly but significantly better than that of their sedentary counterparts. However, in both groups it was far from being a healthy one.

Keywords: Mineral intake - Physical activity - Polish students

\section{Introduction}

In population-based studies the habitual diet in Central and Eastern European countries including Poland was found to be characterized by high intake of fat, protein and processed food, but low intake of complex carbohydrates, fruits, vegetables and dairy products $[7,21]$. Thus, it results in low calcium and magnesium, but excessive phosphorus daily intakes $[18,41]$.

It should be stressed that calcium, magnesium and phosphorus play a key role in a wide range of metabolic functions. It is well documented that calcium $\left(\mathrm{Ca}^{2+}\right)$ is involved in signal transduction in excitable and non-excitable cells acting in both extracellular and intracellular compartments $[4,8,16]$. Magnesium $\left(\mathrm{Mg}^{2+}\right)$ is a cofactor in more than 300 enzymatic reactions and is required for muscle contraction, glucose utilization, and synthesis of nucleic acids, fat and proteins [19]. Phosphorus (inorganic phosphate) is an important component of nucleic acids and high energy nucleotides, and plays an important role in cellular signal transduction [33].

In consequence, any disturbances in calcium, magnesium and phosphorus homeostasis bring about serious health problems. Suboptimal calcium and magnesium dietary intake increases the risk of cardiovascular disease (CVD), insulin resistance, type 2 diabetes, hypertension and osteoporosis [31,34]. Additionally, high dietary phosphorus intake increases the risk of CVD in subjects with normal kidney function and causes hormonal disturbances related to bone health [10].

Numerous studies have shown that dietary habits are related to many factors including age, sex, ethnicity and socio-economic status [38]. There are also data suggesting 
that engagement in physical activity exerts a positive effect on dietary habits of young subjects. Lake et al. [25] demonstrated that active subjects aged 16-20 years consume less fat and more carbohydrates in comparison with their sedentary counterparts. Similarly, many studies have demonstrated a significant positive relationship between fruit and vegetable consumption and participation in physical activity in adolescents and young adults $[1,30,34]$. Moreover, Barzegari et al. [3] noted better nutrition knowledge and food habits in active college students.

Data concerning the association between physical activity and dietary habits in Polish young adults are scarce and concern exclusively lower daily intake of galactose and saccharose in active medical students in comparison with less active ones [14].

Thus, this study was undertaken and aimed at evaluation of energy, macronutrient but also calcium, magnesium, and phosphorus daily intake in young healthy Polish male students with respect to their physical activity.

\section{Materials and methods}

\section{Participants}

A total of 330 male students volunteered to participate in the study. Of them 216 were physical education students engaged in regular physical activity (about $9 \mathrm{~h} /$ week) due to their study program (swimming, games, martial sports) and they were recognized as physically active. One hundred and fourteen students were from other specializations and declared participation in $1.5 \mathrm{~h} /$ week gymnastics classes, and they were recognized as sedentary ones. Participants were recruited on the basis of advertisements in student dormitories and by word of mouth. All participants lived in a big city (over 1 million inhabitants), were non-smokers, and declared that they did not take any vitamin or mineral supplements on a regular basis. Sedentary participants declared their good health before the study, while the health status of active students was confirmed by a medical certificate. Before the study the participants were informed about the procedures involved and gave their written consent. The experimental protocol was accepted by the ethics commission of the Józef Piłsudski University of Physical Education in Warsaw.

\section{Anthropometric measurements}

Body mass and height were measured using standard medical equipment. Body fat was evaluated from four skinfold measurements (biceps, triceps, subscapular and suprailiac) using a Harpenden Skinfold Caliper (British Indicators, Burges Hill, UK). Each measurement was performed twice and was repeated for the third time in the case of discrepancies. The percentage of body fat was calculated according to Durnin and Womersley [13]. Fat mass and lean body mass (LBM) were also calculated.

\section{Dietary records}

In all subjects daily intake of energy, protein, fat, carbohydrates, calcium, magnesium and phosphorus was briefly assessed from 24-hour food records taken over 4 days (2 week days and weekend) and analyzed using the Photo Album of Products and Dishes and computer program Dieta 4.0 purchased from the Institute of Food and Nutrition in Warsaw. A set of pictures of meals and foods were shown to the subjects by an experienced interviewer and household measures of food were converted into gram weights. Subsequently an interviewer assigned codes to the food reported by the participants and performed computer analysis. Daily intakes of calcium, magnesium and phosphorus were referred to Polish recommended daily allowances (RDA), which are $1000 \mathrm{mg}$ /day and $400 \mathrm{mg} /$ day for calcium and magnesium, respectively [20]. Additionally, the ratios of calcium to phosphorus and calcium to magnesium daily intakes were also calculated.

\section{Statistical analysis}

Data distribution was evaluated using the ShapiroWilk test. The Mann-Whitney test was used for data comparison. Significance level was set at $\alpha=0.05$. The results were expressed as the mean $\pm \mathrm{SD}$. All calculations were performed using Statistica v. 10 (StatSoft, Illinois, USA).

\section{Results}

Active and sedentary students did not differ with respect to age, body mass or height (Table 1). Compared to sedentary students, active ones were characterized by significantly lower fat mass and percent of body fat but higher lean body mass $(\mathrm{p}<0.001)$. Daily ener gy and protein intake and the percentage of energy derived from

Table 1. Anthropometric characteristics of active and sedentary male students (mean \pm SD)

\begin{tabular}{lcc}
\hline & $\begin{array}{c}\text { Active students } \\
(\mathrm{n}=216)\end{array}$ & $\begin{array}{c}\text { Sedentary students } \\
(\mathrm{n}=114)\end{array}$ \\
\hline Age [years] & $20.5 \pm 1.5$ & $21.0 \pm 1.9$ \\
Body mass $[\mathrm{kg}]$ & $77.4 \pm 8.9$ & $77.2 \pm 12.2$ \\
Body height $[\mathrm{cm}]$ & $181.6 \pm 6.7$ & $180.4 \pm 6.7$ \\
Fat [\%] & $13.0 \pm 3.9^{\mathrm{a}}$ & $16.6 \pm 5.0$ \\
Fat $[\mathrm{kg}]$ & $10.1 \pm 3.9^{\mathrm{a}}$ & $12.8 \pm 5.3$ \\
LBM $[\mathrm{kg}]$ & $67.3 \pm 6.8^{\mathrm{a}}$ & $64.4 \pm 8.8$ \\
\hline
\end{tabular}

LBM - lean body mass; a $\mathrm{p}<0.001$ - significantly different vs. sedentary students. 
protein in active participants were significantly higher than in their sedentary counterparts $(\mathrm{p}<0.01$ for energy, $\mathrm{p}<0.01$ for protein intake and $\mathrm{p}<0.01$ for energy derived from protein) (Table 2 ). In active students less energy was derived from fat than in sedentary ones $(p<0.001)$. The intake of carbohydrates in grams and the percentage of energy derived from carbohydrates were significantly higher in active students than in sedentary ones $(p<0.001$ and $\mathrm{p}<0.01$ for intake in grams and percentage of energy, respectively). Additionally, active students had significantly higher calcium $(p<0.001)$ and phosphorus $(p<0.01)$ daily intake in comparison with sedentary students. However, $53.2 \%$ of active students but $74.6 \%$ of sedentary ones consumed daily less than $1000 \mathrm{mg}$ of calcium $(\mathrm{p}<0.001)$.
There was no significant difference between active and sedentary males with respect to daily magnesium intake or in fulfillment of its recommended intake. Calculated ratios of calcium to phosphorus and calcium to magnesium in active participants were markedly higher than those in sedentary ones $(p<0.001)$.

Nutritional density of macro - and micronutrients in the diet of active and sedentary male students is presented in Table 3. There was no significant between-group difference in nutritional density of protein or magnesium. In contrast, nutritional density of fat and phosphate was significantly lower in the active students than in the sedentary ones $(p<0.001$ and $p<0.05$ forfatand phosphate, respectively).Additionally, activestudents were characterizedby significantly

Table 2. Daily intakes of energy, macro- and micronutrients in active and sedentary male students $(\mathrm{mean} \pm \mathrm{SD})$

\begin{tabular}{|c|c|c|}
\hline & $\begin{array}{l}\text { Active students } \\
(\mathrm{n}=216)\end{array}$ & $\begin{array}{l}\text { Sedentary students } \\
(\mathrm{n}=114)\end{array}$ \\
\hline Energy [kcal/day] & $2957 \pm 715^{\mathrm{a}}$ & $2756 \pm 682$ \\
\hline Protein $[\mathrm{g}]$ & $108.5 \pm 29.8^{\mathrm{a}}$ & $100.3 \pm 32.4$ \\
\hline Protein [\%] & $15.0 \pm 3.0^{\mathrm{a}}$ & $14.0 \pm 3.0$ \\
\hline Fat $[\mathrm{g}]$ & $119.9 \pm 36.8$ & $120.7 \pm 36.2$ \\
\hline Fat $[\%]$ & $36.0 \pm 6.0^{b}$ & $39 \pm 6.0$ \\
\hline Carbohydrates [g] & $376.8 \pm 100.4^{b}$ & $324.9 \pm 85.0$ \\
\hline Carbohydrates [\%] & $49.0 \pm 6.0^{\mathrm{a}}$ & $47.0 \pm 6.0$ \\
\hline $\mathrm{Ca}^{+2}[\mathrm{mg}]$ & $\begin{array}{c}1064.5 \pm 550.7^{b} \\
(53.2)^{*} \mathrm{~b}\end{array}$ & $\begin{array}{c}844.4 \pm 405.0 \\
(74.6)\end{array}$ \\
\hline $\mathrm{Mg}^{+2}[\mathrm{mg}]$ & $\begin{array}{c}361.0 \pm 110.0 \\
(68.5)\end{array}$ & $\begin{array}{c}352.0 \pm 116.0 \\
(75.4)\end{array}$ \\
\hline $\mathrm{P}_{\mathrm{i}}[\mathrm{mg}]$ & $1730.0 \pm 535.0^{\mathrm{a}}$ & $1573.4 \pm 511.0$ \\
\hline $\mathrm{Ca}^{+2} / \mathrm{P}_{\mathrm{i}}$ & $0.61 \pm 0.16^{b}$ & $0.54 \pm 0.16$ \\
\hline $\mathrm{Ca}^{+2} / \mathrm{Mg}^{+2}$ & $2.9 \pm 1.0^{b}$ & $2.4 \pm 0.9$ \\
\hline
\end{tabular}

${ }^{*}$ - in brackets - percent of students with daily mineral intakes lower than respective RDA; ${ }^{a} \mathrm{p}<0.01 ;{ }^{\mathrm{b}} \mathrm{p}<0.001$ - significantly different vs. sedentary students

Table 3. Nutritional density of macro- and micronutrients in the diet of active and sedentary male students (mean $\pm \mathrm{SD}$ )

\begin{tabular}{lcc}
\hline $\begin{array}{l}\text { Nutritional density } \\
(\mathrm{g} \text { or } \mathrm{mg} / 1000 \mathrm{kcal})\end{array}$ & $\begin{array}{c}\text { Active students } \\
(\mathrm{n}=216)\end{array}$ & $\begin{array}{c}\text { Sedentary students } \\
(\mathrm{n}=114)\end{array}$ \\
\hline Protein & $36.7 \pm 7.0$ & $36.4 \pm 8.1$ \\
Fat & $40.5 \pm 7.0^{\mathrm{a}}$ & $43.8 \pm 6.4$ \\
Carbohydrates & $127.4 \pm 15.1^{\mathrm{a}}$ & $117.9 \pm 16.2$ \\
$\mathrm{Ca}^{2+}$ & $359.9 \pm 145.1^{\mathrm{a}}$ & $306.4 \pm 120.6$ \\
$\mathrm{Mg}^{+2}$ & $122.1 \pm 26.1$ & $126.6 \pm 27.6$ \\
$\mathrm{P}_{\mathrm{i}}$ & $585.0 \pm 126.1^{\mathrm{b}}$ & $610.6 \pm 126.6$ \\
\hline
\end{tabular}

${ }^{\mathrm{a}} \mathrm{p}<0.001 ;{ }^{\mathrm{b}} \mathrm{p}<0.05$ - significantly different vs. sedentary students. 
higher nutritional density of carbohydrates and calcium in comparison with their sedentary counterparts $(\mathrm{p}<0.001$ for both variables).

\section{Discussion}

The most important findings of our study concern the slightly but significantly positive effects of physical activity on dietary habits of male Polish students versus their sedentary counterparts. Their diet contained less fat and phosphorus but more carbohydrates and calcium. These data are in agreement with results from other countries concerning the differences in dietary habits in active young adults in comparison with sedentary ones [22, 24, 27]. The reason for these differences is not fully elucidated, but it seems that active subjects are characterized by better nutritional knowledge than their sedentary counterparts [28].

However, this does not mean that active participants comply with a healthy diet, because in their daily intake the percentage of energy derived from protein and fat was too high, but energy from carbohydrates too low with respect to the recommendations [29]. Moreover, both groups were characterized by inadequate calcium and magnesium but excessive phosphorus intake. Thus, they tend to follow the habitual Polish diet with only minor modifications found in active participants [2, 39, 40].

It should be stressed that in humans the majority of calcium and phosphorus ( $90 \%$ and $99 \%$, respectively) is stored in bones [12]. Additionally, there are data indicating that the ratio of calcium and phosphorus in the diet affects their intestinal absorption, renal filtration and availability for metabolic processes [6]. Much attention has been paid to excessive phosphorus intake due to it detrimental effects on vitamin D synthesis, action and bone status [9]. Our study indicated that the calcium to phosphorus ratio in both active and sedentary students is low, since according to the RDA for both minerals it should be about 1.43:1, but this value was not found in active or sedentary students. However, in active students it was slightly but significantly higher than in sedentary ones. Thus, both groups of participants are possibly at risk of disturbed bone mineralization. This suggestion is in agreement with the findings of Bertrand et al. [5], which indicated inadequate bone mineralization in $26.7 \%$ of male Polish students. In addition, in the Polish population vitamin D deficiency due to climate conditions has to be taken into consideration [26].

Additionally, it should be noted that in healthy Korean adults a low ratio of calcium to phosphorus in the diet (0.5) possibly contributes to disturbed blood levels of total cholesterol and HDL cholesterol [39]. Additionally, Pereira et al. [32] found that a low ratio of calcium to phosphorus in the diet of Brazilian adults (0.57) increases the risk of obesity. Thus, it could not be excluded that due to a low calcium to phosphorus ratio Polish students are at risk of additional health problems as well as decreased bone mineralization.

The lack of difference in magnesium intake in active and sedentary subjects and a similar percentage of subjects with a low magnesium intake suggest that both groups are at risk of magnesium deficiency and its consequences such as type 2 diabetes, CVD and cancer $[15,17,23]$. In addition, taking into account that $60 \%$ of body magnesium is stored in bones and magnesium plays an important role in vitamin D synthesis [36], it seems that in our participants inadequate magnesium intake together with low calcium and high phosphorus possibly contribute to decreased bone mineralization [5].

On the other hand, it seems that the calcium to magnesium ratio in the diet is important for health. In a large Chinese population-based study a calcium to magnesium ratio higher than 1.7 in males was found to be associated with a reduced risk of mortality due to coronary artery disease [11]. A calcium to magnesium ratio lower than 1.7 was found in $8.3 \%$ of active, and in $19.3 \%$ of sedentary participants of our study, with unpredictable health consequences later in life, especially in sedentary ones.

Summing up, our study demonstrated that neither active nor sedentary Polish students presented a pro-healthy dietary pattern since only slight, though significant differences existed in fat, protein, carbohydrate, calcium, phosphorus and magnesium daily intake but also in the ratio of calcium to phosphorus and calcium to magnesium. Thus, taking into account the pronounced effects of minerals on health, their status must be evaluated for detailed health risk studies.

\section{Conflict of interest: Authors state no conflict of interest.}

\section{References}

1. Al-Hazzaa H.M., Abahussain N.A., Al-Sobayel H.I., Qahwaji D.M., Musaiger A.O. (2011) Physical activity, sedentary behaviors and dietary habits among Saudi adolescents relative to age, gender and region. Int. J. Behav. Nutr. Phys. Act., 8: 140.

2. Anyzewska A., Wawrzyniak A., Wozniak A., Krotki M., Górnicka M. (2013) Nutritional assessment in Polish men with cardiovascular diseases. Rocz. Panstw. Zakl. Hig., 64: 211-215.

3. Barzegari A., Ebrahimi M., Azizi M., Ranjbar K. (2011) A study of nutrition knowledge, attitudes and food habits of college students. World Appl. Sci. J., 15: 1017-1017.

4. Berridge M.J., Bootman M.D., Roderick H.L. (2003) Calcium signalling: dynamics, homeostasis and remodelling. Nat. Rev. Mol. Cell. Biol., 4: 517-529. 
5. Bertrandt J., Kłos A., Szymańska W. (2013) Assessment of bone calcification in students from selected universities. Probl. Hig. Epidemiol., 94: 130-133.

6. Blaine J., Chonchol M., Levi M. (2015) Renal control of calcium, phosphate, and magnesium homeostasis. Clin. J. Am. Soc Nephrol., 10: 1257-1272.

7. Boylan S., Welch A., Pikhart H., Malyutina S., Pajak A., Kubinova R., Bragina O., Simonova G., Stepaniak U., Gilis-Januszewska A., Milla L., Peasey A., Marmot M., Bobak M. (2009) Dietary habits in three Central and Eastern European countries: the HAPIEE study. BMC Public. Health, 9: 439.

8. Brown E.M. (2013) Role of the calcium-sensing receptor in extracellular calcium homeostasis. Best. Pract. Res. Clin. Endocrinol. Metab., 27: 333-343.

9. Calvo M.S., Tucker K.L. (2013) Is phosphorus intake that exceeds dietary requirements a risk factor in bone health? Ann. N. Y. Acad. Sci., 1301: 29-35.

10. Calvo M.S., Uribarri J. (2013) Public health impact of dietary phosphorus excess on bone and cardiovascular health in the general population. Am. J. Clin. Nutr., 98: 6-15.

11. Dai Q., Shu X.O., Deng X., Xiang Y.B., Li H., Yang G., Shrubsole M.J., Ji B., Cai H., Chow W.H., Gao Y.T., Zheng W. (2013) Modifying effect of calcium/magnesium intake ratio and mortality: a population-based cohort study. BMJ, Open.; 3.

12. Dermience M., Lognay G., Mathieu F., Goyens P. (2015) Effects of thirty elements on bone metabolism. J. Trace. Elem. Med. Biol., 32: 86-106.

13. Durnin J.V., Womersley J. (1974) Body fat assessed from total body density and its estimation from skinfold thickness: measurements on 481 men and women aged from 16 to 72 years. Br. J. Nutr., 32: 77-97.

14. Grygiel-Górniak B., Tomczak A., Krulikowska N., Przysławski J., Seraszek-Jaros A., Kaczmarek E. (2016) Physical activity, nutritional status, and dietary habits of students of a medical university. Sport Sci. Health, 12: 261-267.

15. Guasch-Ferré M., Bulló M., Estruch R., Corella D., Martínez-González M.A., Ros E., Covas M., Arós F., GómezGracia E., Fiol M., Lapetra J., Muñoz M.Á., Serra-Majem L., Babio N., Pintó X., Lamuela-Raventós R.M., RuizGutiérrez V., Salas-Salvadó J. (2014) Dietary magnesium intake is inversely associated with mortality in adults at high cardiovascular disease risk. J. Nutr., 144: 55-60.

16. Holton M.L., Wang W., Emerson M., Neyses L., Armesilla A.L. (2010) Plasma membrane calcium ATPase proteins as novel regulators of signal transduction pathways. World J. Biol. Chem., 1: 201-208.

17. Hruby A., McKeown N.M, Song Y., Djoussé L. (2013) Dietary Magnesium and Genetic Interactions in Diabetes and Related Risk Factors: A Brief Overview of Current Knowledge. Nutrients., 5: 4990-5011.
18. Ilow R., Regulska-Ilow B., Różańska D., Zatońska K., Dehghan M., Zhang X., Szuba A., Vatten L., Janik-Koncewicz K., Mańczuk M., Zatoński W.A. (2011) Evaluation of mineral and vitamin intake in the diet of a sample of Polish population - baseline assessment from the prospective cohort 'PONS' study. Ann. Agric. Environ. Med., 18: 235-240.

19. Jahnen-Dechent W., Ketteler M. (2012) Magnesium basics. Clin. Kidney. J., 5: i3-i14.

20. Jarosz M., Bułhak-Jachymczyk B. (2008) References in Human Nutrition. PZWL, pp. 233-290.

21. Kardas M., Grochowska-Niedworok E., Całyniuk B., Kolasa I., Grajek M., Bielaszka A., Kiciak A., MucWierzgoń M. (2016) Consumption of milk and milk products in the population of the Upper Silesian agglomeration inhabitants. Food Nutr. Res., 60: 28976 DOI: 10.3402/fnr.v60.28976.

22. Kien C.L., Bunn J.Y., Tompkins C.L., Dumas J.A., Crain K.I., Ebenstein D.B., Koves T.R., Muoio D.M. (2013) Substituting dietary monounsaturated fat for saturated fat is associated with increased daily physical activity and resting energy expenditure and with changes in mood. Am. J. Clin. Nutr., 97: 689-697.

23. Ko H.J., Youn C.H., Kim H.M., Cho Y.J., Lee G.H., Lee W.K. (2014) Dietary magnesium intake and risk of cancer: a meta-analysis of epidemiologic studies. Nutr. Cancer., 66: 915-923.

24. Korn L., Gonen E., Shaked Y., Golan M. (2013) Health perceptions, self and body image, physical activity and nutrition among undergraduate students in Israel. PLoS. One, 8: e58543.

25. Lake A.A., Townshend T., Alvanides S., Stamp E., Adamson A.J. (2009) Diet, physical activity, sedentary behaviour and perceptions of the environment in young adults. J. Hum. Nutr. Diet., 22: 444-454.

26. Lewiński A., Skowrońska-Jóźwiak E.(2014) Calcium and vitamin D supply in Polish population - facts and myths. Ann. Agricult. Environ. Med., 21: 455-456.

27. Moreno-Gómez C., Romaguera-Bosch D., Tauler-Riera P., Bennasar-Veny M., Pericas-Beltran J., MartinezAndreu S., Aguilo-Pons A. (2012) Clustering of lifestyle factors in Spanish university students: the relationship between smoking, alcohol consumption, physical activity and diet quality. Public. Health Nutr., 15: 2131-2139.

28. Nikolaidis P.T., Theodoropoulou E. (2014) Relationship between Nutrition Knowledge and Physical Fitness in Semiprofessional Soccer Players. Scientifica, (Cairo), 2014: 180353.

29. Nutrition standards for the population of the Polish - alteration. Available from: http://www.izz.waw.pl/attachments/article/33/NormyZywieniaNowelizacjaIZZ2012. pdf.

30. Ottevaere C., Huybrechts I., Béghin L., Cuenca-Garcia M., De Bourdeaudhuij I., Gottrand F., Hagströmer M., 
Kafatos A., Le Donne C., Moreno L.A., Sjöström M., Widhalm K., De Henauw S. (2011) Relationship between self-reported dietary intake and physical activity levels among adolescents: the HELENA study. Int. J. Behav. Nutr. Phys. Act., 8: 8.

31. Peacock M. (2010) Calcium metabolism in health and disease. Clin. J. Am. Soc. Nephrol., 5: S23-S30.

32. Pereira D.C., Lima R.P.A., Lima R.T., Gonçalves M.C., de Morais L.C., Franceschini Sdo C., Filizola R.G., de Moraes R.M., Asciutti L.S., Costa M.J. (2013) Association between obesity and calcium:phosphorus ratio in the habitual diets of adults in a city of Northeastern Brazil: an epidemiological study. Nutr. J., 12: 90.

33. Raina R., Garg G., Sethi S.K., Schreiber M.J., Simon J.F., Thomas G. (2012) Phosphorus Metabolism. J. Nephrol. Therapeutic., S3: 008.

34. Romaguera D., Tauler P., Bennasar M., Pericas J., Moreno C., Martinez S., Aguilo A. (2011) Determinants and patterns of physical activity practice among Spanish university students. J. Sports Sci., 29: 989-997.

35. Rosanoff A., Dai Q., Shapses S.A. (2016) Essential Nutrient Interactions: Does Low or Suboptimal Magnesium Status Interact with Vitamin D and/or Calcium Status? Adv. Nutr., 7: 25-43.

36. Rosanoff A., Weaver C.M., Rude R.K. (2012) Suboptimal magnesium status in the United States: are the health consequences underestimated? Nutr. Rev., 70: 153-164.

37. Skowrońska-Jóźwiak E., Jaworski M., Lorenc R., Karbownik-Lewińska M., Lewiński A. (2017) Low dairy calcium intake is associated with overweight and elevated blood pressure in Polish adults, notably in premenopausal women. Public. Health Nutr., 20: 630-637.

38. Sleddens E.F., Kroeze W., Kohl L.F., Bolten L.M., Velema E., Kaspers P.J., Brug J., Kremers S.P. (2015) Determinants of dietary behavior among youth: an umbrella review. Int. J. Behav. Nutr. Phys. Act., 12: 7.

39. So-Young B., Myung-Hwa K., Eun-Jin K., Choi M.K. (2012) Dietary Intake Ratios of Calcium-to-Phosphorus and Sodium-to-Potassium Are Associated with Serum Lipid Levels in Healthy Korean Adults. Prev. Nutr. Food. Sci., 17: 93-100.

40. Śmidowicz A., Reguła J. (2015) Dietary gender differences in terms of the risk of atherogenesis in Poland. Acta. Sci. Pol. Technol. Aliment., 14: 257-267.

41. Waśkiewicz A., Szcześniewska D., Szostak-Węgierek D., Kwaśniewska M., Pająk A., Stepaniak U., Kozakiewicz K., Tykarski A., Zdrojewski T., Zujko M.E., Drygas W. (2016) Are dietary habits of the Polish population consistent with the recommendations for prevention of cardiovascular disease? - WOBASZ II project. Kardiol. Pol., 74: 969-977.

\section{Received 10.04.2017 \\ Accepted 25.09.2017}

(C) University of Physical Education, Warsaw, Poland 